\title{
Editorial: Geryon and Occupy
}

'Ecco colei che tutto 'l mundo appuzza!': 'Behold him who infects the whole world!', namely the beast Geryon, who takes Dante from the usurers to the fraudulent in Canto XVII of Inferno. 'Foul image of fraud' Geryon may be, locust-or serpent-like in his lower quarters, but his face was the face of a just man, gracious in its outward aspect. Why, though, we may ask, is usury akin to fraud? And would Dante have had more time for the rag-taggle 'occupiers' of our financial centres than for the smooth faced and immaculately attired banker and traders they are protesting about?

For Dante, as for many medievals, there was something deeply unnatural about making money out of money itself. Money could be legitimately used for productive ends, and indeed profits were permissible were any made from investing money for agricultural or industrial purposes. What was unnatural was having 'benefit of interest on all the moneys which it, the bank, creates out of nothing'. It is this creating of prodigious moneys out of nothing other than other moneys, or out of bets on other moneys or from even more non-existent things such as possible future prices, which is intuitively troubling to many. Over and above bankers' pay, questions such as these seem to be at the root of much of the current unease with our banking systems.

Some may look to the dowager-like Bank of England or to its correctly unglamorous governor to introduce some solidity into the situation. Unfortunately for this view, having benefit of interests which it creates out of nothing was advertised as one of that bank's benefits by William Paterson, its co-founder, as far back as 1694. It seems that, for all its ostensible respectability, deep down the practice of the Bank of England may be no more natural or righteous than any other.

There are metaphysical issues here, as well as ethical. Is the usury that was condemned by the medieval Church really a magical conjuring something out of nothing, more akin to alchemy than to honest work? Even if it were, in what sense would that be unnatural? And even if unnatural, does that make it ethically or politically objectionable? Are the occupiers simply victims of a throw-back to longsurpassed medieval superstition, irrationally spooked by the abstract but hugely beneficial methods of modern economies (as Hayek suggested)? And should they be worried that the objections to banking just raised here were the same as those which obsessed Ezra Pound in the 1930s - with, to say the least, unfortunate results? 


\section{Editorial}

The occupiers themselves are doubtless too busy with their living arrangements and dealing with endless legal challenges to ponder such philosophical matters, but the questions involved may touch a nerve even with some of those who benefit from the system in question, let alone with those intuitively opposed to it. There is scope here for philosophical investigation. 